\title{
Leadership: \\ Three Approaches to Learning
}

Regina F. Bento, (Email: rbento@ubalt.edu), University of Baltimore

Barry Brownstein, (Email: bbrownstein@ubalt.edu), University of Baltimore

Susan Rawson Zacur, (Email: szacur@ubalt.edu), University of Baltimore

\begin{abstract}
This paper describes three approaches to teaching leadership at the advanced level for adult learners. The three approaches address competence or skill building and authenticity or self-development. Each approach offers a variety of materials to draw from and provides concrete examples of learning activities.
\end{abstract}

\section{INTRODUCTION}

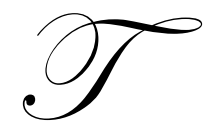

raditional approaches to teaching leadership often focused on theories, tools, and techniques (Ferris, 1998). These approaches transmitted information about leadership rather than developing the capacity for leadership in the individual learners. Scholars recognized this limitation within the past decade (Kouzes \& Pozner, 1995; Doyle \& Smith, 1999; Nirenberg, 1998). Leadership from within (McDermott, 1994) emphasizes personal leadership development consistent with an understanding of the importance of credibility, soul, emotions, openness to experience, and values (Ferris, 1998; Bolman \& Deal, 1995; Steiner \& Gaskin, 1998; Sankar, 2003).

Philosopher Peter Koestenbaum says, "Think of leadership as the sum of two vectors: competence (your specialty, your skills, your know-how) and authenticity (your identity, your character, your attitude)" (LaBarre, 2001). Competence and authenticity are recurring themes in three graduate level courses on leadership that are described in this article. The courses focus on practical skill enhancement while fostering value-based thinking and character development. The courses offer distinct approaches to the study of leadership that can stand-alone or be combined into an MBA specialization, as they are at our University.

The purpose of this article is to describe three approaches to learning leadership via graduate level coursework. The descriptions provide sufficient content and material to assist other faculty, leadership trainers, and executive coaches in development of their own learning initiatives. The courses are delivered in different formats ranging from in-person, to web assisted, to totally on the web. Each course summary includes some of the learning highlights from the students' perspectives to help facilitators enliven their sessions with breakthrough experiences that make a significant difference to the learners.

The sections that follow are organized to provide course background, description, objectives, and an account of the course experience.

\section{THE LEADERSHIP SEMINAR}

\section{Background}

Inspiration for this course came from academic work and professional experience. The creator of this course has an academic background in organizational behavior, human resource management, and related fields. A professional background in human resource management, continuing exposure to the business community, leadership coaching projects, and experience in designing and delivering custom leadership programs for senior administrators in 
business firms all influenced the design of this course. Course outline drafts were reviewed with business advisors including an Executive in Residence. The latest version of the course outline can be found at http://home.ubalt.edu/ntsbzacu/731.html.

\section{Course Description}

The Leadership Seminar focuses on critical issues pertaining to success in operating at the executive level in business and other organizations. This seminar presumes technical knowledge in one's field and seeks to provide skills and insights to enhance the learner's capability for leading at a high organizational level. Topics include personal leadership behaviors, communication skills for leaders, ethical perspectives, customer orientation, vision and strategic direction, effective decision making, performance maximization, human asset management, capital liquidity, and information technology.

\section{Course Objectives}

Upon completion of the Leadership Seminar, students should be able to:

- Describe the behaviors that distinguish leaders from others in their work environments

- Demonstrate skills in communicating to external constituencies including stakeholders and the media.

- $\quad$ Articulate a set of values that will provide benchmarks for leading.

- $\quad$ Explain how a leader fosters customer orientation.

- Create a vision statement.

- $\quad$ Distinguish where a decision should appropriately be made in an organization and identify ways to foster decision-making by others.

- $\quad$ Plan approaches to maximizing the performance of people in organizations.

- $\quad$ Perform succession planning and devise compensation approaches to reward stars.

- $\quad$ Create a plan for capital liquidity that will appeal to financial backers.

- $\quad$ Generate a leader's position on information technology as a force for change.

\section{The Course Experience}

Course requirements include extensive reading from selected texts and journal articles. Students also choose a selection from a leadership book list and then give an oral report in a Reading Roundtable. Students are assigned to a particular roundtable based on their book choice so that titles are not duplicated within the group at each table. Students provide a written executive summary and then present the book to the group. Students then discuss all of the books and search for insights to enhance their understanding of leadership. The group prepares answers to the following questions that are then presented to the entire class after the Roundtable meetings:

- $\quad$ Identify ten essential leadership behaviors

- $\quad$ Identify five character traits essential to good leadership

- $\quad$ Provide a definition of great leadership

Each student submits a written book report along with the executive summary for grading.

The term project for this course is a Leadership Journal. The journal provides a record of the entire course with summaries of the lessons learned in each class meeting, reflections on assigned readings, a personal values statement, self assessment based on instruments provided and discussion of personal fitness for the leadership challenges described in the class, and summaries of additional readings and resources on leadership.

Each class meeting starts with a member of the class presenting a briefing on the assigned reading for that class meeting. The text of the briefing must fit on two sides of a $3 \times 5$ file card and must succinctly present the key points of the reading. This is a graded assignment that gives the students practice in concise oral presentation as 
leaders. The professor then highlights key concepts for the topic of the day. Activities follow which may include case discussions, experiential exercises, guest speakers, skill practice, or leadership assessments.

Feature films are a highly useful resource for case material in a leadership class. Students seem to grasp leadership concepts and understand behaviors quickly as they watch the work of skilled actors. Films that are highlighted in case discussions may include Gandhi, Thirteen Days, Patton, Lawrence of Arabia, Elizabeth, Glory, Gettysburg, Crimson Tide, and The Hunt for Red October. Many of these films are the basis for leadership cases developed by the Hartwick Humanities in Management Institute (Hartwick, 2004). Students enjoy searching for and citing other films that have scenes depicting leadership. They also say that they will never look at a film as merely entertainment again after using films as leadership cases.

Values Rummy (Hughes, 2001) is one experiential exercise that stands out for students in this class. Working in groups of 5-7, students are dealt hands of six cards with different values printed on them. They play six rounds of rummy picking up and discarding values in an effort to get a hand that best represents their own personal values. At the end of the card game, students may add values and discard others in order to obtain their personal list of six core values. The students enjoy sharing their experience in playing the game and especially point out the fun they have in seeing what values their classmates discard.

The professor then asks students to think about the way they currently live their lives at work, with friends, and at home and how they spend their money to determine for themselves whether their behaviors are consistent with their values. An essay on their personal values, based on this exercise, is required as part of their Leadership Journal term project.

Each topic addressed in the course is aimed at the leadership level. For example, when discussing personal leadership behaviors, the focus is on how to behave as a professional, how to network at that level, how to conduct one's personal life in a professional manner so that background checks for important positions yield favorable results. When discussing communication skills, the emphasis is on responding to the media in a crisis situation, appearing before TV cameras for a studio interview, and giving a speech as the leader of an organization. When discussing effective decision making, students learn techniques for driving decisions down to the operating level as well as what decisions to reserve for leadership. Thus, content is focused above the middle management level to provide students with a skill set essential for executive level work.

The Leadership Seminar focuses on the vector of competence. It provides academic content coupled with vivid examples of desired behaviors. Students have opportunities to lead various aspects of the course and the opportunity to try out behaviors in experiential exercises. The vector of authenticity is touched upon when personal values need to be articulated. This vector is strengthened through the students' exposure to the other two leadership courses.

\section{LEADERSHIP, LEARNING AND CHANGE}

\section{Background}

Leadership, Learning and Change was designed to help students learn something that cannot be taught: leading, learning and changing from within. The core idea in the course design is that learning about leadership is a journey not just of the mind, but of the spirit. The deeper we go into the exploration of organizational leadership, learning and change, the more we need to deal with the dimensions of sense-making, connection-building, choicemaking, vision-inspiring, reality-creating roles of leaders. This exploration expands on the vector of authenticity, while providing leadership practices to build competence.

The pilot version of the course was developed during a Visiting Professorship at MIT and was discussed in the Journal of Management Education special issue on Spirituality in the Workplace (Bento, 2000). Subsequent versions of the course have been taught in the Saturday MBA and WebMBA programs at our university. The latest version of the syllabus is online at http://home.ubalt.edu/rbento/leadlearnchange.htm. 


\section{Course Description}

The course involves as a series of readings, assignments, and web forum interactions designed to inspire "practices of deep reflection:" storytelling, historical inquiry, reflective reading and writing, dialogue, action research (Wisely and Lynn, 1994).

The entire course is based on a metaphorical approach to the leadership and change journey. The syllabus describes the course as a small inn at a crossroads where the personal journeys of all participants (faculty and students) converge. There we can think and talk about where we come from and where we are going in our journeys. We can share resources, gain new energy and build provisions of knowledge and skills that will help us get where we want to go, and to learn along the way.

For the duration of the course, this metaphorical inn hosts a "retreat" on organizational leadership, learning and change. Just as musicians and music lovers come together yearly at the Tanglewood festival, in these metaphorical leadership retreats we get together to perfect our craft, engage in individual and team exploration, and push our performance to new levels.

The role of the faculty member is that of an "innkeeper," who puts together a variety of experiences, events and resources to welcome the retreat participants, and to help them reflect and build on what they have learned so far in their careers and lives about leadership, learning and change. The choices made in stocking up the inn necessarily reflect the faculty member's own background, interests and beliefs. But what happens next is largely up to the participants, who are encouraged to take leadership of the course and make their own choices.

The retreat evolves in a series of workshops, led by teams of students, focusing on topics such as:

- The Knowing-Doing Gap: an exploration of the ways in which talk can substitute for action in organizations, the forces that keep organizations from acting on the knowledge they already possess, and ways of bridging that gap (Pfeffer and Sutton, 1999).

- $\quad$ The Language of Leadership and Change: an exploration of the story-telling role of leaders and change agents, the limits of conventional language and the potential of other forms of expression such as fables (Aesop, n.d.), collages (Pink, 1998a, 1998b), music (Seifter, 2001), metaphors (Morgan, 1986), stories (Tichy, 1997; Weil, 1998) and film (e.g., Chaplin's Modern Times).

- The Right Stuff: an exploration of what it takes to be a leader, using historical inquiry and personal experience to look at leaders in public and private arenas (Goodwin, 1998; Mintzberg, 1999), the search for meaning in organizations (Handy, 1997) and how challenges may create the opportunity for greatness (Kouzes \& Posner, 2003).

- $\quad$ The Better Mousetrap: an exploration of the visionary aspects of leadership, the challenges of nurturing creativity, change and innovation, and how individuals and organizations can honor the past without becoming its prisoners (Bridges \& Mitchell, 2000; De Pree, 2001; Drucker, 1998; Grove, 1998; Senge, 1998).

- $\quad$ Circle of Power: an exploration of factors that breed fear in people and organizations, how to keep fear from obstructing the path that links knowledge to action, and how individuals and groups can achieve power and influence (Bennis, 1997; Goleman, 2002; Heifetz \& Linsky, 2002; Hock, 2000; Katzenbach, 1998; Kotter, 2003; Schlesinger, 1996).

- $\quad$ Folly, Reality and Possibility: an exploration of the leader's role in framing perceived reality (Plato, 360 BCE), the uses and misuses of measurement and how it can obstruct good judgement and create toxic organizations (Hammer, 2002; Pfeffer \& Sutton, 1999; Smith, 2000).

- Culture, Leadership and Change: an exploration of how organizational culture and leadership can support or stifle change and innovation (Deering et al, 2003; Hamel, 2003; Handy, 2002; Linden, 2003; Wheatley, 2001).

- $\quad$ Finding your Voice: an exploration of the challenge of "being who you are" and leading from within, discovering and acting on the core truths of people and organizations (Drucker, 2000; Kelleher, 1997; McDermott, 1994; Meyerson, 2002). 


\section{Course Objectives}

At the end of their "stay at the inn," participants should be able to:

- $\quad$ Analyze and discuss the knowing-doing gap in organizations and propose changes to reduce that gap in a variety of situations: when talk substitutes for action; when memory is a substitute for thinking; when fear prevents acting on knowledge; when measurement obstructs good judgment; and when internal competition turns friends into enemies.

- Apply "right brain" metaphorical approaches (fables, storytelling, collages, music, movies, literature, drama etc.) to go beyond surface knowledge and reach deeper thoughts, feelings, attitudes, perceptions and meanings.

- $\quad$ Identify and discuss personal models of leadership.

- $\quad$ Recognize and tap into the sources of power in organizations and society.

- Preserve and enhance the ability to see through "the Emperor's new clothes" and counteract the pressures for groupthink and conventional wisdom.

- $\quad$ Sharpen their ability to predict and identify the occurrence of discontinuous change in the marketplace, in order to create opportunities and/or avoid the threats of under-the-radar, "segment zero" competition.

- Develop further insight into their purpose and calling in life, and nurture the ability to apply this knowledge to continuing the journey towards leadership from within.

\section{The Course Experience}

Possibly the best way to learn about leadership is by leading. In this "retreat at the inn," course participants form a learning community where each week different teams lead the workshops by conducting discussions about the readings and assignments, and expanding the collective knowledge with additional resources, experiences and examples. A basic assumption is that the responsibility for learning is equally and actively shared by all the course participants.

The leadership role of students also extends to an area usually reserved for faculty, through the "Adopt-ABook" project. As in any regular course, there are required readings, shared by all students, which include two books (Pfeffer \& Sutton, 1999; Hesselbein \& Cohen, 1999) and numerous articles, available as links in the syllabus. But the ownership and passion that come with selecting a book are not reserved only for the faculty. Each student also gets to "adopt" a book and becomes our resident expert on that book, drawing from it whenever appropriate as they participate in the discussions throughout the course, and sharing a comprehensive book review at the end. Over the years, students have come up with exhilarating choices of books, and the process of choosing and sharing their "own" texts brings extraordinary energy to the discussions, and is part of the experience of finding one's voice.

The "First Person" assignments represent another path for pursuing "leadership from within". Each week, depending on the theme for the workshop, students engage in the creation of collages, fables, stories, essays, notes, cases, web pages, and other forms of creative expression that allow them to examine and share a significant experience in their leadership journeys.

An interesting aspect of the course experience is that the intensity and nature of the interpersonal exchanges do not seem to depend on the delivery medium. Whether the "retreat at the inn" takes place face-to-face (in weekly meetings of 3.5 hours on Saturdays) or online (in asynchronous, weeklong threaded discussions using the Prometheus platform), the power of the experience seems to remain the same. As a matter of fact, the ultimate test of the portability of the course design across different media came from two apparently contradictory student comments: "I cannot imagine this course being taught online" (a face-to-face student) and "I cannot imagine this course being taught in a classroom" (an online student). Students in both environments are equally enthusiastic about the course, produce work of the same quality, and report a similar blend of individuality and interaction - what McDermott (1994) calls the experience of being "apart" (unique), while at the same time being "a part" of a community. 
At the end of their stay at the metaphorical inn, participants say that they have gained an intimate and deeper knowledge of each other, and of themselves. They establish a deep attachment to the journey companions they meet at the "inn" and their interpersonal bonds often continue long after the official course has ended. Course evaluations are consistently high, and emphasize the opportunity of taking leadership of one's own learning of leadership. Students appreciate the experience of both leading and participating in a vibrant learning community through dialogue, collaboration, critical thinking and reflective action. Participants report having gained insights into the value-driven, moral and spiritual dimensions of leadership, and a direct understanding of how leaders have to dig deep into the mystery of themselves to make value judgments, to inspire others, and to recognize "moments of truth" as calls for ethical decision-making and action.

One of the most appreciated aspects of the course experience is the personalization and customization made possible by features such as the "First Person" assignments, the "Adopt-a-Book" project and the weekly workshops. All these elements work like the little pieces of a photo-mosaic (see, for example, http://www.photomosaic.com/rt/3.htm). When course participants arrive at the inn, they find it stocked with many little pieces that can all share. As the retreat goes on, they also bring in other pieces that best fit their own experiences and interests. If they succeed in making the course really work for them, they leave the inn with a photo-mosaic that uniquely reflects who they were, who they are, and who they want to be in their leadership journeys.

\section{LEADERSHIP: SELF-ORGANIZATION IN THE FIRM}

\section{Background}

Leadership: Self-Organization in the Firm approaches leadership issues from the vantage point of selforganizing or complex adaptive systems. It explicitly addresses the vector of authenticity and has two major objectives. The first major objective is to discover the management principles and processes that promote and foster self-organization as an alternative to command and control hierarchies. The second major objective of this course has to do with the process of personal discovery.

The philosophical foundation for this course stems from two fundamental principles found in the work of Nobel laureate Friedrich Hayek. The first of these is that the order we seek within our organizations is not solely the product of planning and control. The second principle is the understanding that knowledge is dispersed (Hayek, 1945). This understanding has profound implications for knowledge management within organizations. Order can be generated spontaneously, without planning and control. Spontaneous order is "the product of action of many men but are not the result of human design." (Hayek, 1973, p. 38). There are many examples of self-organizing systems in the natural world and in many aspects of the social world including free markets and now in business organizations that make the choice to organize themselves under the principles of self-organization.

Taken together, dispersed knowledge and self-organizing systems not only challenge traditional views of organization but they challenge us to rethink the role of leaders and even redefine leadership. Since an organization has a specific purpose, it cannot operate as a pure spontaneous order or as a pure complex adaptive system; but it can use the ideas from both to improve the efficiency of the organization. The goal is for a leader to effectively utilize the organization intelligence that is inherently dispersed throughout the organization.

Recent work in chaos theory, quantum physics, and complexity science, complemented the work of Hayek in economics, and gained a broader audience with applications to business and management. Tom Petzinger's book (1999) "The New Pioneers" documents the transformation of organizations from traditional command and control management to self-organizing systems. Physicist David Bohm's (1996) work on dialogue has been applied to communication skills in business. David Whyte (1994) has used poetry to facilitate personal and organizational transformation required by business applications of the new science of self-organization. The course draws together theoretical frameworks in the new sciences and practical business applications to examine the implications for leadership. 
It is useful to recognize that traditional concepts of management and leadership are built on the Newtonian ideas that the world is a predictable and linear machine. If you do A then you get B in a predictable manner. However complexity sciences recognizes that: "modern organizations and institutions are so interconnected, both internally and externally, that we can never expect to follow all of the intricate connections in the hope of sorting our linear causes and effects." (Youngblood, 1997, p. 13).

Youngblood (1997, p.34) lists these properties of self-organizing systems:

- $\quad$ They are wholes that are greater than the sum of their parts.

- $\quad$ They are open systems operating far from equilibrium that continually renew themselves through reciprocal interactions with their environments.

- $\quad$ They have the capacity to spontaneously create new forms of order, behavior and structure.

- $\quad$ They are interconnected in complex, non-linear ways.

- $\quad$ They are both autonomous from, and merged with, their environments.

Self-organization can be defined "'as the tendency of certain (but not all) systems operating far from equilibrium to shift to a new state when their constituent elements generate unlikely combinations." (Pascale, Millemann \& Gioja, 2000, p. 113 ). Similarly complex adaptive systems (CAS) have "the ability to adapt to a changing environment... (and) are characterized by the potential for self-organization." (Goldstein, 2001). Rules play a critical role in how adaptable and flexible a CAS is. Dee Hock, the founding CEO of Visa, (1999) brilliantly summed up the roles of rules: "Simple, clear purpose and principles give rise to complex, intelligent behavior. Complex rules and regulations give rise to simple, stupid behavior." (p. 89).

Hayek, complexity theorists, and those management practitioners such as Hock, who have applied these ideas, recognize that life's natural tendency is to organize. Life thus organizes into greater and greater levels of complexity to support more and more diversity and greater sustainability. This complexity is beyond the scope of the human mind to comprehend fully. Markets, language, and the Internet are all examples of spontaneous orders or selforganizing systems. Although we can't fully comprehend spontaneous order, we can benefit by it. In the world of computing for instance, programs such as Linux with open source codes are making rapid market gains. Some such as Thomas Petzinger (1999) believe that self-organizing systems are the future of business management.

Turning to the second objective of the course, parallel principles of spontaneous order operate at the level of the organization and at the level of the individual. As a result, a highly leveraged form of change in an organization is leadership through inner transformation and discovery. Personal discovery or the "inner side of leadership" (Brownstein, 2003) is vital to organizational transformation. Dee Hock has written:

"Once you understand that you and your organization are inseparable (since every organization only exists in your mind) then the idea that it's about individual change or organizational change, and that one can proceed independently of the other, is utter nonsense." (Hock, 2000).

A leader in a self-organizing or complex adaptive system emerges according to the needs of the organization at the time. Michael McMaster writes:

"At the moment that leadership occurs, it appears as though the individual is leading and that this action is the result of that person's leadership qualities. We see leadership embodied in a single individual. But if we look beyond the surface, we will see that this phenomenon has emerged...it is ...an interaction." (McMaster, 1996, p. 71).

Once we understand the value of the ideas of self-organizing systems in creating an adaptable, sustainable firm we understand that leadership is not a matter of personality or style but rather a matter of the theory that a leader uses. McMaster observes: "Leadership without a distinct theory is merely a phenomenon of personality and will not survive the particular leader. More importantly, it will seldom have more than a temporary impact on a corporation." (McMaster, 1996, p. 69). 
Through these ideas adopted from complex adaptive systems, students of the course take with them the lasting idea that effective leadership does not stem from supreme competence, exhorting control over others or superior ability to foresee the future. Rather the act of leadership stems from in part from the ability to utilize organizational intelligence that is inherently dispersed throughout the organization.

\section{Course Description}

The course is designed using the principles of self-organization. Students experience a learning environment that encourages and facilitates the type of self-responsibility, self-reflection and out-of-the-box thinking that selforganizing systems rely upon to tap into and utilize dispersed knowledge. Self-organization is based on the idea that simple rules can promote a very complex and robust learning environment that facilitates individual transformation. The course is designed around simple rules where students:

- $\quad$ Prepare for each class by completing the assigned readings on time and analyze and consider each reading for its contribution to an integrative whole.

- $\quad$ Are active participants in the group and class dialogues, keeping in mind that good dialogue depends on good listening skills.

- $\quad$ Participate in the supplementary web forum dialogue.

- $\quad$ Are actively involved in journal writing each week. In the journal, students reflect on ideas and principles that they find compelling and uncover the barriers in themselves and their organization that stand in the way of implementation. They tie their reflections back to specific ideas in the course material and readings.

The course description reads as follows: "The course covers self-organizing systems, complexity theory in management, dialogue as a management tool, leadership in a complex system, pursuing a personal discovery process, and growing new knowledge and innovation. A major objective of this course is to discover the management principles and processes that promote and foster self-organization as an alternative to command and control hierarchies. The course draws out the profound implications of self-organization for growing new knowledge and innovation. A second major objective of this course has to do with the process of personal discovery. Parallel principles of spontaneous order operate at the level of the organization and at the level of the individual. As a result, a highly leveraged form of change in an organization is leadership through personal growth and discovery."

The latest version of the course syllabus is available at: http://home.ubalt.edu/bbrownstein/mgmt732/ fall2004web.mht.

\section{Course Objectives}

Upon completion of this course students should be able to:

- $\quad$ Appraise the value of self-organization in business.

- $\quad$ Evaluate how to organize an organization for complexity.

- Demonstrate commitment to uncover hidden beliefs that limit effectiveness as leaders.

- $\quad$ Examine dialogue skills as a means of uncovering and creating new knowledge and shared meanings.

- $\quad$ Appraise the value of the discovery process in the firm and in personal/professional lives.

- Recognize spontaneous order and how it helps us to facilitate leveraged change in our firms and personal/professional careers.

- $\quad$ Recognize that knowledge is dispersed and demonstrate commitment to using dispersed knowledge in organizations.

- $\quad$ Examine tacit knowledge and how to use tacit knowledge in our firms.

- $\quad$ Examine the "implicate order" and its implication in business and our professional life.

- $\quad$ Evaluate the role spirituality can play in business and our professional career.

- $\quad$ Recognize that we are part of a larger emerging movement in business.

- $\quad$ Assess what leadership means in a complex adaptive system. 
- Demonstrate commitment to be more engaged and increase the engagement of employees.

\section{The Course Experience}

The course is set up to encourage refection on the part of the active participant. Mintzberg (2004) encourages an MBA curriculum that facilitates the students stepping back and reflecting on "interesting ideas." The role of the professor is not as "sage on the stage" but as a "guide on the side" who, although a few step ahead of the students, is essentially taking the same journey.

In class and group dialogues students are encouraged to uncover and examine their own personal beliefs about the topic introduced in the class. Our assumptions, beliefs, and paradigms are frequently transparent to us, yet they play an essential role in how we interpret and react as leaders. "Beliefs, assumptions, concepts, and information retrieved from memory form a mind-set or mental model that guides perception and processing of new information." (Heuer, 1999).

By not working to be aware of our beliefs we limit our ability to engage others. An ongoing process of inquiry and reflection is necessary. A class atmosphere where asking questions with the "intention of gaining additional insight and perspective" is encouraged. Students are encouraged to assume they don't know; in Zen this is called "beginner's mind." Always searching, always discovering and reflecting on ideas that have life to us, is the one of the secrets of effective leadership.

This ongoing process of reflection is essential for a leader. Parker Palmer points out:

"A leader is a person who has an unusual degree of power to create the conditions under which other people must live and move and have their being, conditions that can be as illuminating as heaven or as shadowy as hell. A leader must take special responsibility for what's going on inside his or her own self, inside his or her consciousness, lest the act of leadership do more harm than good." (Palmer, 1990, p. 5).

Students of the course are encouraged to engage in a process of reflection. The skills of dialogue and journal writing, which are practiced in the course, support this process.

Small group work also supports the process of ongoing reflection. Students are assigned to permanent small groups of seven to eight. Nine small group exercises have been written for this course. The exercises use required reading material and often encourage students to try out new concepts or conduct their own informal observations in their workplaces. Students report experiencing genuine insights when their reflections during group exercises help them to uncover and examine their own beliefs. Here is an example of one of these group exercises:

\section{Strange Attractors}

Simple rules facilitate spontaneous orders and complex systems, but there are other ingredients in spontaneous orders. In this exercise we explore the concept of strange attractors, borrowed from complexity science.

Wheatley (2001, p. 22-23) explains strange attractors as follows: "A system is defined as chaotic when it becomes impossible to know what it will do next. The system never behaves the same way twice. But as chaos theory shows, if we look at such a system over time, it demonstrates an inherent orderliness. Its wild gyrations are held within an invisible boundary. The system holds order within it, and reveals this self-portrait as a beautiful pattern, its strange attractor."

Whyte (1994, p. 246) uses the motion of a pendulum to describe strange attractors: "Even the most chaotic of pendulum swings will never overstep certain boundaries; it will move within a shape that we come to recognize as the pendulum's strange attractor." 
Mike McMaster in his "core code" talks (2000, p. 8) about the related concept of attraction: "The major force that keeps elements coordinating and building a common future is not boundaries, rules or prohibitions. ..The major force is attraction.... That is, it is those organizations where the major force is attraction (value, principles, fun, personal growth) which exhibit energy and focused coordinated action that works."

Using your readings over this week please reflect on the following and use these questions to facilitate your group dialogue:

- $\quad$ Can I state the basic principles of my life? What do I value?

- "What theories do you have about motivation and why people work?"

- What language do I use to describe myself?

- How much quiet time do I provide myself so I do remember my simple principles, in the course of daily life?

- $\quad$ "How much resemblance does my daily work bear toward these principles?" (Whyte, 1994, p. 300).

- $\quad$ "How well does my organization embody the things I deem most important?" (Whyte, 1994, p. 304).

- " $\quad$ "How do I currently talk about my business?" (McMaster, 1996, p.42).

- $\quad$ "Will this way of speaking lead to the future I want or will it merely continue to extend what is already in existence?" (McMaster, 1996, p.42).

- What language patterns exist in me and in my organization "that inhibit the expansion of values, goals and possibilities." (McMaster, 1996, p.42).

- $\quad$ "How would you like the people of your corporation to think about the company?" (McMaster, 1996, p.42).

- "Does your way of speaking encourage that way of thinking in others or not?" (McMaster, 1996, p.42).

How is a transformational experience facilitated in this course?

- An extensive reading lists of books and articles that help facilitate the exploration of new ideas.

- $\quad$ Part of the class-time is spent in dialogue with the professor which begins with his selection of ideas, quotes and interpretations from the readings.

- $\quad$ Part of the class-time is spent in group break-out (7 or 8 in a group). The group begins with the exploration of questions contained in a group exercise written by the professor and expands from there.

- $\quad$ A web-based 24/7 Forum to explore ideas when class is not in session.

- $\quad$ Dialogue skills are practiced at all times to encourage an atmosphere of safety.

- Students are required to keep a journal in which they give ongoing meaning and life to the reading material. They reflect on ideas and principles that they find compelling and uncover the barriers in themselves and their organization that stand in the way of implementing them.

- A class atmosphere that is respectful of every student and respectful of the process of reflection that creates opportunities for insight and transformation.

Students describe the course as a transformational experience. Students frequently report that the course required them to use more of themselves than other courses; that the course is a journey into the "inner-self"; and that the course planted a seed that continues to grow and flourish as long as they tend their new emergent "garden".

\section{CONCLUSION}

The three approaches to leadership learning address Kostenbaum's vectors of competence and authenticity (LaBarre, 2001). The discussion of each course provides sufficient detail for readers to draw from in creating their own material to address competence or authenticity. A distinct characteristic that these approaches have in common is the role of the facilitator as a co-learner. It is only fair when asking for authentic transformation from learners to ask for willingness of the facilitator to be transformed. As McMaster (1996, p. 184) advises leaders: "We are going to have to accept the challenges of personal development before we demand the same of others." 


\section{REFERENCES}

1. Aesop (No date). Aesop's Fables. http://sailor.gutenberg.org/by-author/ae0.html.

2. $\quad$ Bennis, W. (1997). "The secrets of great groups". Leader to Leader, 3 (Winter), 29-33.

3. Bento, R. (2000). "The little inn at the crossroads: A spiritual approach to the design of a leadership course". Journal of Management Education, vol. 24, no.5, pp. 650-661.

4. Bohm, D. (1996). On dialogue. New York: Brunner-Routledge.

5. Bolman, L. and T. E. Deal (1995). Leading with soul: An uncommon journey of spirit. San Francisco: Jossey-Bass.

6. Bridges, W. and S. Mitchell (2000). "Leading transition: A new model for change". Leader to Leader, 16 (Spring), 30-36.

7. Brownstein, B. (2003). The Inner Side of Leadership Parts 1, 2, 3, 4. The Brownstein Letter http://lists.topica. com/lists/BrownsteinLetter/read.

8. $\quad$ De Pree, M. (2001). "Creative leadership". Leader to Leader, 20 (Spring), 10-13.

9. Deering, A., R. Dilts, and J. Russell (2003). "Leadership cults and cultures". Leader to Leader, 28 (Spring), 36-43.

10. Doyle, M.E. and M. K. Smith (1999). Born and bred? Leadership, heart, and informal education. London: YMCA George Williams College/The Rank Foundation.

11. Drucker, P. (1999). "The discipline of innovation". In Frances Hesselbein \& Paul M. Cohen (Eds.). Leader to leader: enduring insights on leadership. San Francisco: Jossey-Bass.

12. Drucker, P. (2000). "Managing knowledge means managing oneself". Leader to Leader, 16 (Spring), 8-10.

13. Ferris, W.P. (1998). "Fear, stress and second-guessing in leadership decision making: using interior monologues, reflective nonfiction, and spiritual approaches". Journal of Management Education, 22(1), 26-48.

14. Goldstein, J. (2001). "Edgeware glossary". http://www.plexusinstitute.com/edgeware/archive/think/main _gloss3.html\#c10.

15. Goleman, D. (2002). "Leading resonant teams". Leader to Leader, 25 (Summer), 24-30.

16. Goodwin, D. K. (1998). "Lessons of presidential leadership". Leader to Leader, 9 (Summer), 23-30.

17. Grove, A. S. (1999). "Managing Segment Zero". Leader to Leader, 11 (Winter), 16-21.

18. Hamel, G. (2003). "Innovation as a deep capability". Leader to Leader, 27 (Winter), 19-24.

19. Hammer, M. (2002). "Why leaders should reconsider their measurement systems". Leader toLeader, 24 (Spring), 34-38.

20. Handy, C. (1997). "The search for meaning". Leader to Leader, 5 (Summer), 14-20.

21. Handy, C. (2002). "Elephants and fleas: is your organization prepared for change?" Leader to Leader, 24 (Spring), 29-33.

22. "Hartwick humanities in management institute". Hartwick College, Oneonta, New York. Retrieved from www.hartwick.edu/hhmi/academicindex.htm.

23. Hayek, F. (1945). "The use of knowledge in society". American Economic Review, 35 (September), 519-30.

24. Hayek, F. (1973). Law, legislation and liberty. Chicago: University of Chicago Press.

25. Heifetz, R. A. \& Linsky, M. (2002). "Leading with an open heart". Leader to Leader. 26 (Fall), 28-33.

26. Hesselbein, F. \& Cohen, P. (1999). Leader to leader: enduring insights on leadership. San Francisco: JosseyBass.

27. Heuer, R (1999). Psychology of intelligence analysis. Central Intelligence Agency. http://www.cia.gov/ csi/books/19104.

28. Hock, D. (1999). Birth of the chaordic age. San Francisco: Berret-Koehler.

29. Kotter, J. P. (2003). "The power of feelings". Leader to Leader, 27 (Winter), 25-31.

30. Kouzes, J.M. and Posner, B.Z. (1995). The leadership challenge. San Francisco: Jossey-Bass.

31. Kouzes, J. M., and Posner, B. Z. (2003). "Challenge is the opportunity for greatness". Leader toLeader, 28 (Spring), 16-23.

32. LaBarre, P. (2001). "Do you have the will to lead?" In W.E. Rosenbach and R.L. Taylor (Eds.), Contemporary Issues in Leadership (pp. 65-71). Boulder, Colorado: Westview Press.

33. Linden, R. (2003). "The discipline of collaboration". Leader to Leader, 29 (Summer), 41-47.

34. McDermott. (1994). "Partnering with God: ignatian spirituality and leadership in groups". In J. Conger (Ed), Spirit at work: discovering the spirituality in leadership (pp. 132-161). San Francisco: Jossey-Bass. 
35. McMaster, M. (1996). The intelligence advantage. Newton, MA.: Butterworth-Heinemann.

36. McMaster, M. (2000). "Core code - processes for developing an entrepreneurial organization”. (Unpublished Manuscript).

37. Meyerson, D. (2002). "Everyday leaders: the power of difference". Leader to Leader, 23 (Winter), $29-34$.

38. Mintzberg, H. (1999). "Managing quietly". Leader to Leader, 12 (Spring), 24-30.

39. Mintzberg, H. (2004). Managers not MBAs. San Francisco: Berret-Koehler.

40. Morgan, G. (1986). Images of organization. Beverly Hills: Sage.

41. Nirenberg, J. (1998). "Myths we teach, realities we ignore: leadership education in business schools". The Journal of Leadership Studies, 5 (1), 82-99.

42. $\quad$ Palmer, P. (1990). Leading From Within. Indianapolis: Indiana Office for Campus Ministries.

43. Pascale, R., M. Millemann, and L. Gioja (2000). Surfing The Edge of Chaos. New York: Crown.

44. Petzinger, T. (1999). The new pioneers. New York: Simon and Schuster.

45. Pink, D. (1998). "Metaphor marketing". Fast Company. Retrieved from http://www.fastcompany.com/ online/14/zaltman.html.

46. Pink, D. (1998b). "This is my brain on coffee”. Fast Company. Retrieved from http://www.fastcompany. com/ online/14/coffee.html.

47. Pfeffer, J. and R. I. Sutton (1999). The Knowing-Doing Gap. Boston: Harvard Business School.

48. Plato (n.d.). "The Republic Book VII". Retrieved from http://classics.mit.edu/Plato/republic.html.

49. Sankar, Y. (2003). "Character not charisma is the critical measure of leadership excellence". The Journal of Leadership and Organizational Studies, 9 (4), 45-55.

50. Schlesinger, L. (1996). "It doesn't take a wizard to build a better boss". Fast Company, 3 (June/July), 102.

51. Seifter, H. (2001). "The conductor-less orchestra". Leader to Leader, 21 (Summer), 38-44.

52. Senge, P. M. (1998). "The practice of innovation". Leader to Leader, 9 (Summer), 16-22.

53. Smith, D. K. (2000). "Better than plan: managing beyond the budget". Leader to Leader, 15 (Winter), $33-39$.

54. Steiner, C.J. \& Gaskin, P. (1998). "Educating leaders: from the abstract and rational to the concrete and personal". The Journal of Leadership Studies, 5 (2), 83-102.

55. Tichy, Noel M. (1997). "The mark of a winner". Leader to Leader, 6 (Fall), 24-29.

56. Weil, E. (1998). "Every leader tells a story". Fast Company, 15 (June), 38.

57. Wheatley, M. (1999). Leadership and the New Science (2nd ed). San Francisco: Berret-Koehler.

58. Wheatley, M. J. (2001). "Innovation means relying on everyone's creativity". Leader to Leader, 20 (Spring), 14-20.

59. Whyte, D. (1994). The Heart Aroused. New York: Currency-Doubleday.

60. Wisely, D. S. \& Lynn, E. M. (1994). "Spirited connections: Learning to tap the spiritual resources in our lives and work". In J.A. Conger (Ed.), Spirit at Work: Discovering the spirituality in leadership. San Francisco: Jossey-Bass.

61. Youngblood, M. (1997). Life at the edge of chaos. Dallas: Percival. 